め，パネル作成や開発品の展示をどのようにすれば学会参 加者へ興味を持ってもらえるか, 長い時間をかけて検討し てきた．幸いなことに一連の展示物は多くの学会参加者に 興味を持って頂くことができたうえ, 今後の開発のヒント になる情報も得ることができたようである，例えば，竹一
プラスチックコンポジット材では機械的強度特性等につい て, 小型射出成形機と加工刃物の開発品では成形精度等に ついて議論が交わされていた.

今後も, 企業が本セッションへの出展を活かし，ものづ くり技術の高度化に取り組まれることを期待したい.

\title{
ポスターセッション
}

田上秀 一*

ポスターセッションは, 成形加工シンポジアでここ数年, 最初のセッションとして定着している感がある. 今回も大 会初日の午前中に行われた。今年も会場が参加者の熱気に 満ちあふれ，あちこちで活発なディスカッションが行われ るという，いつもの光景が見られた．今回は 108 件という 多くのエントリーがあった。ここ数年, ポスターセッショ ンは 100 件超えが続いている.

さて，恒例となっているべストポスター賞には 82 件の エントリーがあり，41名の審査委員による厳正な審査が 行われた。今年は例年にもなく評価が拮抗し，審査委員の 皆様も優劣をつけるのに苦労されている様子であった。そ の結果，次に紹介する 9 件の発表者がベストポスター賞を 受賞した。祝意・敬意を示しつつ，発表題目とともにご紹 介させて頂く

田村 勇太氏 (東京大学)

「ブラスト表面処理を利用した金属/樹脂直接接合の基礎 的検証」

伊藤 友貴氏 (北陸先端科学技術大学院大学)

「直鎖状ポリエチレンブレンドにおける流動不安定現象 と混練履歴の関係」

佐藤 春馬氏 (北陸先端科学技術大学院大学)

「ポリプロピレン/ポリブテンー 1 ブレンド押出成形体の 分子配向制御」

本田＼cjkstart慎一郎氏（住友ゴム工業）

「シリカ充填エラストマーの流動特性」

\footnotetext{
* Tanoue, Shuichi

福井大学大学院工学研究科

福井市文京 3-9-1（=910-8507）
}

倉田 陽介氏（東京工業大学）

「光重合を用いた分子配向性フィルムの作製とメカニズ 厶の検討

高山 哲生氏（山形大学）

「塩基性硫酸マグネシウムウイスカ充填ポリプロピレン の力学的特性に及ぼすナノシリカ粒子分散の影響」

高木 芽衣氏（山形大学）

「金属イオン種がエチレン系アイオノマー/スチレンーメ タクリル酸共重合体ブレンドの溶融レオロジーとモル フォロジーに与える影響」

佐光 巧氏 (北陸先端科学技術大学院大学)

「ポリメタクリル酸メチルの添加と表面局在化によるポ リカーボネートの表面特性改質」

\section{谷島 大介氏（立教大学）}

「水崩壊性ポリ乳酸ブレンドの加水分解挙動：ブレンド の高次構造および $\mathrm{pH}$ 条件の影響」

表彰は初日の夜に開催された懇親会の中で行われ，八尾 実行委員長より各受賞者に記念の盾が贈られた.また, 受賞 者を代表して山形大の高山哲生氏より挨拶を頂いた．表彰 式の後は関係者と受賞の喜びを分かち合う光景が見られた。 成形加工シンポジアのポスターセッションは時間に制限 なくディスカッションができるという醍醐味がある。その 分野の大御所もポスターの前に訪れることも多く，貴重な アドバイスももらえ，得るものもたくさんある．ポスター セッションに活気がある限り，成形加工分野の未来は明る い.そう思えるセッションであった。

最後に，ご多忙の中，多くのみなさまに審査委員をお引 き受け頂き，ご協力頂きました。この場をお借りして，厚 くお礼申し上げます。 